\title{
Effect of Some Feed Additives on In Vitro Rumen Digestibility
}

\author{
Derya Merve Karagoz (Corresponding author) \\ Department of Animal Nutrition, Faculty of Veterinary Medicine, \\ Burdur Mehmet Akif Ersoy University, Burdur, Turkey \\ E-mail: dmarituluk@mehmetakif.edu.tr,derya_merve_arituluk@hotmail.com \\ Mustafa Numan Oguz \\ Department of Animal Nutrition, Faculty of Veterinary Medicine, \\ Burdur Mehmet Akif Ersoy University, Burdur, Turkey \\ E-mail:mnoguz@yahoo.com \\ Ismail Bayram \\ Department of Animal Nutrition, Faculty of Veterinary Medicine, \\ Afyon Kocatepe University, Afyonkarahisar, Turkey \\ E-mail: ibayram1965@gmail.com
}

\begin{abstract}
Researchers have recently focused on studies involving the improvement of feeds and their digestibility using different feed additives. These studies include feed additives such as probiotics, prebiotics, enzymes, organic acids, and phytobiotics. Feed additives added to feeds at appropriate levels increase the amount and quality of animal products, digestibility of feeds, feed consumption, and feed utilization. Various methods have been developed to determine digestibility, which is one of the determinants of the quality of feeds, accurately and reliably. Since chemical analyses do not reveal the actual value of feed or feed additives, various digestive experiments such as in vivo, in situ, and in vitro digestibility have been developed and used. In vivo experiments are reliable, but they have disadvantages of being cumbersome and expensive. Consequently, in vitro experiments have been preferred more recently due to easier execution in a short time span at cheaper costs, lesser requirement of feed material, and controlled experimental conditions. This review is aimed to highlight the available information regarding the use of feed additives in in vitro rumen digestion experiments.
\end{abstract}

Keywords: In vitro digestibility, Feed additive, Ruminant.

\section{Special Issue of Health Sciences}

DOI: $10.7176 / \mathrm{JSTR} / 7-08-02$

\section{Introduction}

The increase in the world population has increased the need for animal origin protein. Ruminants are in a unique position to meet the increasing demand for animal origin protein (Badhan et al., 2018). With the increase in the world population, agricultural land is constantly decreasing (Karakuş et al., 2019). Therefore, it requires an increase in productivity of animals, the addition of new feedstuffs, and increasing the nutritive value of existing feedstuffs (van der Poel et al., 2020). One possible way is the use of feed additives (Wenk, 2000). Recently, researchers have focused on investigating the use of feed additives as digestive system regulatory agents (Tawab et al., 2021; Ogunade \& McCoun, 2021; Seifdavati et al., 2021).

The development of methods that allow accurate and reliable determination of digestibility, which is one of the factors that determine the feed quality, has been the focus of researchers' interest for many years. Different methods such as in vivo, in vitro, and in situ are used to determine the feed values of the feeds used in ruminant feeding. Although the results of in vivo studies are generally more reliable, in vitro methods are preferred more recently due to disadvantages of in vivo studies such as 
difficult, expensive, high workload, long time required, difficulty in experiment conditions control, and the need for more feed samples (Adesogan, 2005; Kılıç \& Sarıçiçek, 2006; Tassone et al., 2020). Some in vitro digestion techniques are RUSITEC (Rumen Simulation Technique) (semi-open system), Daisy Incubator (closed system), Tilley Terry's two-stage digestion process, Goering and Van Soest (1970) method, enzyme method, and gas production techniques.

The RUSITEC system is a semi-continuous closed incubation model that obtains values very close to the results obtained in in vivo animal experiments. It basically consists of fermenters kept in water baths with a temperature of $39^{\circ} \mathrm{C}$ and perforated inner containers placed in them (Szarkowski \& Breckenridgee, 1977).

Goering and Van Soest (1970) developed neutral detergent fiber (NDF) and acid detergent fiber (ADF) methods to estimate the digestibility of components associated with feed ingredients. The NDF enables the determination of cell wall components (hemicellulose, cellulose, lignin) whereas, ADF determines the residues of cellulose and lignin (Kellems \& Church, 2010).

In the Daisy Incubator device, a closed in vitro system, four independent jars each equivalent to a rumen environment are used. Nutrient analysis (NDF, Dry matter (DM), Organic matter (OM)) is carried out for the samples remaining in the bags after incubation (Tassone et al., 2020). The ANKOM Daisy Incubator method (ANKOM Technology, Macedonia, NY, US) enables the incubation of more than one sample also, automates the incubation environment, and eliminates manual handling in sample processing (Adesogan, 2005; Tassone et al., 2020).

Tilley and Terry's (1963) in vitro digestibility measurement technique consist of two stages. In the first stage, feed samples, rumen fluid, and the buffer solution are incubated under anaerobic conditions at 39 ${ }^{\circ} \mathrm{C}$ for 48 hours that imitates the fermentation process in rumen. In the second stage, insoluble proteins are broken down by treatment with an acid-pepsin solution for 48 hours $(\mathrm{pH}=2)$. The disadvantage of this method is that it takes a long time and is inconvenient (Baran et al., 2017).

One of the methods used to determine the nutritional value of feeds is the gas production technique. Hohenheim (Menke) gas production technique is the most widely used gas production technique of today. It is a feed evaluation method based on the measurement of gases (methane $\left(\mathrm{CH}_{4}\right)$, carbon dioxide $\left(\mathrm{CO}_{2}\right)$, etc.), which are the final products of fermentation (Menke et al., 1979; Kılıç \& Sarıçiçek, 2006).

Ruminants digest structural carbohydrates (cellulose, hemicellulose) through anaerobic fermentation by cellulolytic microorganisms (bacteria, protozoa, and fungi) in the rumen (Badhan, 2018). However, ruminants cannot digest about $20-70 \%$ of the cellulose in the feed. Therefore, not all feed energy can be considered as net energy (Kocaoğlu Güçlü \& Kara, 2010). Limited penetration of cellulolytic microorganisms into the plant cell, insufficient retention time of feed in the rumen, and limiting enzyme activity are the reasons for the restriction of cellulose digestion in the rumen (Badhan, 2018).

Low cellulose digestibility reduces the feed conversion ratio and performance of ruminant animals. Improving the cellulose degradability in rumen provides additional energy to ruminants and increases the nutritional value of feeds (Riberio et al., 2018). One of the ways to improve the cellulose degradability is the use of feed additives that should be evidence based. It requires the evaluation of the effects of feed additives on the ruminal digestibility of nutrients. Studies on the use of alternative feed additives such as probiotics (bacteria, fungi, and yeast), prebiotics, enzymes, organic acids, and phytogenics in ruminants have increased in recent years. The purpose of this review is to evaluate the effects of feed additives that have been used in in vitro digestion experiments of ruminants in recent years.

\section{Enzymes}

Enzymes being bioactive proteins are biological catalysts that carry out chemical reactions by acting on specific substrates (Gado et al., 2017). Dietary supplemental enzymes increase the nutrient utilization in the digestive system and neutralize the undesirable antinutritional factors in feeds. Enzyme preparations used in ruminants are obtained from bacteria (Lactobacillus plantarum, Bacillus subtilis, Lactobacillus acidophilus, and Streptococcus faecium), fungi (Trichoderma longibrachiatum, Aspergillus oryzae, and Trichoderma reesei), and Saccharomyces cerevisiae yeast (McAllister et al., 2001).

Studies involving the use of exogenous enzymes in ruminant diets date back to the $1960 \mathrm{~s}$. However, the inconsistent results obtained, the unknown mechanism of action of enzymes, and high production costs have limited the developments in this field. With the recent advances in biotechnology, reduction of enzyme production cost, and better-defined commercial enzyme products, the knowledge of potential use of exogenous enzymes to increase feed utilization in ruminants has evolved (Sujana \& Seresinhe, 2015).

11 I P a g e

www.iiste.org 
Recently, it has been reported that exogenous fibrinolytic enzymes increase the digestibility of feeds in in vitro rumen digestion studies (Kondratovich et al., 2019; Li et al., 2019; Santoso et al., 2020). Factors such as the mode of action of exogenous enzymes, the type of animal used, compatibility between exogenous enzymes, and rumen microflora affect the enzyme activity. Abdi \& K1liç (2018) reported that lignin peroxidase enzyme increased the lignin digestibility of wheat straw, soy straw, and sorghum straw. Kondratovich et al. (2019) reported an improvement in the digestibility of corncob, especially sorghum grain, sorghum grain, wheat straw, cottonseed hulls, rape, soybean hulls, and alfalfa following supplementation of Trichoderma reesei extract containing xylanase. It was observed that cellobiohydrolase enzyme produced from Pichia pastoris yeast originating from Lentinula edodes fungus increased the cellulose digestibility of rice, wheat, and corn straws ( $\mathrm{Li}$ et al., 2019). Santoso et al. (2020) revealed that increasing cellulase doses increased the in vitro dry matter, in vitro organic matter, and NDF digestibility of silage made from agricultural waste (Table 1).

Table 1: Some studies examining the effect of enzymes on in vitro digestibility recently

\begin{tabular}{|c|c|c|c|c|c|}
\hline $\begin{array}{l}\text { Animal } \\
\text { Species }\end{array}$ & Enzyme & $\begin{array}{l}\text { Feed used } \\
\text { (Substrate) }\end{array}$ & $\begin{array}{c}\text { In vitro } \\
\text { digestibility } \\
\text { method }\end{array}$ & Dose & References \\
\hline Bull & Lignin peroxidase & $\begin{array}{l}\text { wheat straw, } \\
\text { soybean straw, } \\
\text { sorghum straw }\end{array}$ & $\begin{array}{l}\text { ANKOM Daisy } \\
\text { II Incubator }\end{array}$ & $\begin{array}{l}1 \text { enzyme unit for } \\
\text { every } 10 \text { grams of } \\
\text { straw }\end{array}$ & $\begin{array}{l}\text { Abdi \& Kilıç, } \\
2018\end{array}$ \\
\hline $\begin{array}{l}\text { Beef } \\
\text { steers }\end{array}$ & $\begin{array}{l}\text { Trichoderma reesei } \\
\text { fermentation } \\
\text { extract; exogenous } \\
\text { xylanase }\end{array}$ & $\begin{array}{l}\text { corncobs, sorghum } \\
\text { grain, wheat straw, } \\
\text { cotton burrs, corn } \\
\text { stalks, cottonseed } \\
\text { hulls, grape } \\
\text { pomace, soybean } \\
\text { hulls, LQ alfalfa, } \\
\text { sorghum stalks, } \\
\text { sorghum dry } \\
\text { distillers' grains. }\end{array}$ & $\begin{array}{l}\text { ANKOM Daisy } \\
\text { II Incubator }\end{array}$ & $0.75 \mu \mathrm{L} / \mathrm{g}$ & $\begin{array}{l}\text { Kondratovich } \\
\text { et al., } 2019\end{array}$ \\
\hline $\begin{array}{l}\text { Beef } \\
\text { steers }\end{array}$ & $\begin{array}{l}\text { Recombinant } \\
\text { cellobiohydrolase } \\
\text { produced by Pichia } \\
\text { pastoris }\end{array}$ & $\begin{array}{l}\text { rice straw, wheat } \\
\text { straw, corn straw }\end{array}$ & $\begin{array}{l}\text { Gas production } \\
\text { technique }\end{array}$ & $\begin{array}{l}8 \text { ug enzyme for } \\
\text { every } 20 \mathrm{mg} \\
\text { straw }\end{array}$ & Li et al., 2019 \\
\hline Cattle & Cellulase & $\begin{array}{l}\text { agricultural wastes } \\
\text { (feed silage } \\
\text { containing oil palm } \\
\text { frond and rice crop } \\
\text { residue) }\end{array}$ & $\begin{array}{l}\text { Tilley and } \\
\text { Terry (1963) } \\
\text { technique }\end{array}$ & $\begin{array}{l}1 \mathrm{ml} / \mathrm{kg}, 2 \mathrm{ml} / \mathrm{kg} \\
3 \mathrm{ml} / \mathrm{kg}, 4 \mathrm{ml} / \mathrm{kg}\end{array}$ & $\begin{array}{l}\text { Santoso et al., } \\
2020\end{array}$ \\
\hline
\end{tabular}

\section{Probiotics}

Probiotics are non-pathogenic and non-toxic living microorganisms that can have a beneficial effect on host animals at appropriate doses, proliferate as implanted in the intestines, are not absorbed from the digestive tract, and show antagonistic effect against pathogenic microorganisms (Arowolo \& He, 2018). In addition, probiotics are naturally occurring live microorganisms that improve the digestive system of live animals (Elghandour et al., 2015). Probiotics have a potential substitute for antibiotics and widely used in the feed industry (Hassan et al. 2019). Probiotics commonly used in ruminants include yeast ( $S$. cerevisiae) and bacterial species such as Bacillus, Bifidobacterium, Enterococcus, Lactobacillus, Propionibacterium, Megasphaera, and Prevotella (Arowolo \& He, 2018).

Live $S$. cerevisiae is one of the most common and effective probiotics used in ruminant nutrition because it stabilizes the rumen environment for adequate functioning of microbial flora, particularly fibrolytic bacteria (Arowolo \& He, 2018). Adding S. cerevisiae directly to sorghum straw or preincubation for 72 hours increased gas production, DM, and NDF digestibility (Elghandour et al., 2014). Ogunade and McCoun (2021) examined the effect of red clover-orchardgrass hay on in vitro digestibility by adding $S$. cerevisiae and Aspergillus-based enzyme to beef cattle diets. Compared to the control group, there was no difference in in vitro digestibility in the experimental group containing $S$. cerevisiae and the experimental group containing Aspergillus-based enzyme. However, in vitro dry matter and NDF digestibility increased in the experimental group containing $S$. cerevisiae and

12 | $\mathrm{P}$ a g e

www.iiste.org 
Aspergillus-based enzymes (Table 2).

The use of bacterial probiotics as ruminant feed additives can increase DM consumption, cellulose digestibility, and growth performance (Hassan et al., 2019). Rhodopseudomonas palustris is a gramnegative photosynthetic bacterium that is common in nature (Chen et al., 2020). Chen et al. (2020) concluded that Rhodopseudomonas palustris promoted the growth of rumen microorganisms and maintained the anaerobic environment of rumen required for microbial fermentation. Hassan et al. (2019) reported that the powder and liquid forms of Ruminococcus flavefaciens bacteria increase in vitro dry matter digestibility (Table 2). Seifdavati et al. (2021) investigated the the effect of wastes of wheat straw, wheat bran, and urea (WU) treated with probiotic (PR) and organic acids (OA) on ruminal gas production and digestibility of pumpkin by-product (PB) silage. They reported an improvement in $\mathrm{DM}$ and $\mathrm{OM}$ digestibility with increasing level of $\mathrm{PB}$ and probiotic supplementation.

Table 2: Some studies examining the effect probiotics on in vitro digestibility recently

\begin{tabular}{|c|c|c|c|c|c|}
\hline $\begin{array}{l}\text { Animal } \\
\text { Species }\end{array}$ & Probiotic & $\begin{array}{l}\text { Feed used } \\
\text { (Substrate) }\end{array}$ & $\begin{array}{c}\text { In vitro } \\
\text { digestibility } \\
\text { method }\end{array}$ & Dose & References \\
\hline Cow & S. cerevisiae & sorghum straw & $\begin{array}{l}\text { Goering and } \\
\text { Van Soest } \\
(1970) \\
\text { technique }\end{array}$ & $\begin{array}{l}4 \mathrm{mg} / \mathrm{g} \mathrm{DM}, \\
8 \mathrm{mg} / \mathrm{g} \mathrm{DM}, \\
12 \mathrm{mg} / \mathrm{g} \mathrm{DM}\end{array}$ & $\begin{array}{l}\text { Elghandour } \\
\text { et al., } 2014\end{array}$ \\
\hline $\begin{array}{l}\text { Beef } \\
\text { steers }\end{array}$ & $\begin{array}{l}\text { S. cerevisiae } \\
\text { Aspergillus } \text {-based } \\
\text { enzyme extracts }\end{array}$ & $\begin{array}{l}\text { red clover- } \\
\text { orchardgrass hay }\end{array}$ & $\begin{array}{l}\text { Gas production } \\
\text { technique }\end{array}$ & $\begin{array}{l}\text { Control (CON) } \\
\text { (basal diet without } \\
\text { additive) } \\
\text { S. cerevisiae }(\mathrm{SC}) \\
\text { (CON+15 g/day of } \\
\text { live SC), } \\
\text { Aspergillus-based } \\
\text { enzyme extracts } \\
(\mathrm{ABE}), \\
(\mathrm{CON}+5 \mathrm{~g} / \text { day of } \\
\mathrm{ABE}) \\
\mathrm{SC}+\mathrm{ABE}(15 \mathrm{~g} / \mathrm{d} \text { of } \\
\text { live } \mathrm{SC}+5 \mathrm{~g} \text { of } \\
\mathrm{ABE}) .\end{array}$ & $\begin{array}{l}\text { Ogunade \& } \\
\text { McCoun, } \\
2021\end{array}$ \\
\hline Cow & $\begin{array}{l}\text { Rhodopseudomonas } \\
\text { palustris }\end{array}$ & Total Mix Ration & $\begin{array}{l}\text { Gas production } \\
\text { technique }\end{array}$ & $\begin{array}{l}0,1.3,2.6,3.9 \\
5.2 \times 10^{6} \mathrm{cfu} / \mathrm{ml}\end{array}$ & $\begin{array}{l}\text { Chen et al., } \\
2020\end{array}$ \\
\hline Lamb & $\begin{array}{l}\text { Ruminococcus } \\
\text { flavefaciens }\end{array}$ & $\begin{array}{l}\text { concentrate feed } \\
(\% 60)+\text { rice } \\
\text { straw }(\% 40)\end{array}$ & $\begin{array}{l}\text { Gas production } \\
\text { technique }\end{array}$ & $\begin{array}{l}\text { powder }(20 \mathrm{~g}) \text { or } \\
\text { liquid }(10 \mathrm{ml})\end{array}$ & $\begin{array}{l}\text { Hassan et al., } \\
2019\end{array}$ \\
\hline Sheep & Probiotic* & $\begin{array}{l}\text { pumpkin by- } \\
\text { product (PB) } \\
\text { silage }\end{array}$ & $\begin{array}{l}\text { ANKOM Daisy } \\
\text { II Incubator }\end{array}$ & $\% 0.1$ & $\begin{array}{l}\text { Seifdavati et } \\
\text { al., } 2021\end{array}$ \\
\hline
\end{tabular}

*Probiotic includes dried Lactobacillus plantarum, sugar, dried mushrooms, di-potassium phosphate, glycine, magnesium sulfate, sodium aluminum oxide, sodium erythorbate.

\section{Prebiotics}

Prebiotics is a form of substrates used selectively by health-beneficial host microorganisms. Prebiotics have benefits such as inhibition of pathogenic microbes in the digestive system, activation of the immune system, and vitamin synthesis (Cherry et al., 2019). Prebiotics contain carbohydrates that produce essential fatty acids. Prebiotics can improve the nutrient digestibility and feed efficiency (Singh et al., 2017).

Crude glycerin is a residue from biodiesel production. Glycerin is fermentable into propionate in the 
rumen. Increased propionate concentration in the rumen will reduce $\mathrm{H}$ availability and consequently methane production. Seankamsorn et al. (2020) reported that the addition of $21 \%$ crude glycerin to TMR diets with $2 \%$ chitosan supplementation increased ruminal propionate concentration and reduced methane production without adversely affecting gas kinetics or nutrient digestibility (Tablo 3). Chitosan is a biopolymer found in the exoskeletons of crabs and shrimp. Chitosan can also reduce methane production by changing the volatile fatty acid (VFA) profile in the rumen. Goiri et al. (2010) reported that the use of chitosan increased the propionate ratio in the rumen of sheep diet without affecting nutrient digestibility. Li et al. (2018) evaluated the effect of bioactive polysaccharides and oligosaccharides on ruminal fermentation, feed digestibility, and biohydrogenation. They reported that the xylooligosaccharides (XOS) group increased the DM, NDF, and ADF digestibility within 24 hours whereas no change was noted after 48 hours of incubation compared with control and glucose (GLU) groups. APS (Astragalus polysaccharide), LBP (Lycium barbarum polysaccharide), FOS (fructooligosaccharide) or COS (chitooligosaccharide) supplementation had no effect on nutrient digestibility. Singh et al. (2020) reported that the inclusion of mannan oligosaccharides in aflatoxincontaminated feed partially improved the in vitro rumen fermentation parameters (Tablo 3 ).

Inulin belongs to a class of carbohydrates known as fructans. Inulin is a natural fructooligosaccharide linked to $\beta$ (2-1) commonly found in plants (Singh et al., 2017). The 2,1- link inulin protects the upper part of the gastrointestinal tract from digestion. It has been reported that the use of high-dose inulin $(300 \mathrm{mg} / \mathrm{L})$ in perennial rye decreases in vitro dry matter digestibility, while low-dose inulin (100 $\mathrm{mg} / \mathrm{L}$ ) increases in vitro dry matter digestibility (Tablo 3 ).

Table 3: Some studies examining the effect prebiotics on in vitro digestibility recently

\begin{tabular}{|c|c|c|c|c|c|}
\hline $\begin{array}{l}\text { Animal } \\
\text { Species }\end{array}$ & Prebiotic & $\begin{array}{l}\text { Feed used } \\
\text { (Substrate) }\end{array}$ & $\begin{array}{l}\text { In vitro } \\
\text { digestibility } \\
\text { method }\end{array}$ & Dose & References \\
\hline $\begin{array}{l}\text { Dairy } \\
\text { cattle }\end{array}$ & $\begin{array}{l}\text { Crude Glycerin, } \\
\text { Chitosan }\end{array}$ & $\begin{array}{l}\text { Total Mix Ration } \\
\text { (TMR) }\end{array}$ & $\begin{array}{l}\text { Gas } \\
\text { production } \\
\text { technique }\end{array}$ & $\begin{array}{l}\text { crude glycerin }(0, \\
10.5, \text { and } 21 \% \text { of } \\
\text { TMR }), \\
\text { chitosan }(0,1, \text { and } \\
2 \% \text { DM of substrate })\end{array}$ & $\begin{array}{l}\text { Seankamsorn } \\
\text { et al., } 2020\end{array}$ \\
\hline Goat & $\begin{array}{l}\text { Bioactive } \\
\text { polysaccharides } \\
\text { and } \\
\text { oligosaccharides } \\
\text { (POSs) } \\
\end{array}$ & Basal diet & $\begin{array}{l}\text { Rumen } \\
\text { Simulation } \\
\text { Technique } \\
\text { (RUSITEC) }\end{array}$ & $10 \mathrm{~g} / \mathrm{kg}$ diet & $\begin{array}{l}\text { Li et al., } \\
2018\end{array}$ \\
\hline Sheep & Inulin & $\begin{array}{l}\text { corn silage, } \\
\text { perennial } \\
\text { ryegrass, vetch/oat } \\
\text { hay }\end{array}$ & $\begin{array}{l}\text { ANKOM } \\
\text { Daisy II } \\
\text { Incubator }\end{array}$ & $\begin{array}{l}0,100,200,300 \\
\mathrm{mg} / 1\end{array}$ & $\begin{array}{l}\text { Salman et } \\
\text { al., } 2017\end{array}$ \\
\hline Buffalo & $\begin{array}{l}\text { mannan } \\
\text { oligosaccharides }\end{array}$ & Basal feed & $\begin{array}{l}\text { Gas } \\
\text { production } \\
\text { technique }\end{array}$ & $0,0.05,0.1,0.2 \%$ & $\begin{array}{l}\text { Singh et al., } \\
2020\end{array}$ \\
\hline
\end{tabular}

\section{Organic Acids}

Organic acids formed by the oxidation of an aldehyde group include lactic acid, formic acid, oxalic acid, malonic acid, malic acid, acetic acid, succinic acid, aspartic acid, citric acid, pyruvic acid, fumaric acid, and their salts. Organic acids are used in the feeding of farm animals to increase the acidity of feeds and prevent feed spoilage, maintain the balance between pathogens and beneficial microorganisms (probiotics) in the digestive system, improve the digestion and absorption of nutrients, stimulate growth, and to promote health (Kocaoğlu Güçlü \& Kara, 2010).

Zhang et al. (2017) reported that treatment of drooping wild ryegrass (Elymus nutans Griseb.) silage with $3 \mathrm{~g} / \mathrm{kg}$ formic acid increased cumulative gas production but did not affect in vitro rumen digestibility. Harder et al. (2015) concluded that citric acid or lactic acid treatment can be used to counteract the adverse effects of fiber digestion in grains. Genç et al. (2020) revealed that $0.1 \%$ fumaric acid treatment increases the in vitro organic matter digestibility of either tea factory waste or tea tree leaves as potential alternative feed sources for ruminants. 
Table 4: Some studies examining the effect organic acids on in vitro digestibility recently

\begin{tabular}{|c|c|c|c|c|c|}
\hline $\begin{array}{l}\text { Animal } \\
\text { Species }\end{array}$ & Organic acid & $\begin{array}{l}\text { Feed used } \\
\text { (Substrate) }\end{array}$ & $\begin{array}{l}\text { In vitro } \\
\text { digestibility } \\
\text { method }\end{array}$ & Dose & References \\
\hline Cow & Formic acid & $\begin{array}{l}\text { drooping wild } \\
\text { ryegrass (Elymus } \\
\text { nutans Griseb.) silage }\end{array}$ & $\begin{array}{l}\text { Gas production } \\
\text { technique }\end{array}$ & $3 \mathrm{~g} / \mathrm{kg}$ & $\begin{array}{l}\text { Zhang et } \\
\text { al., } 2017\end{array}$ \\
\hline Cow & $\begin{array}{l}\text { Citric acid } \\
\text { Lactic acid }\end{array}$ & barley & \begin{tabular}{|l|} 
Rumen \\
Simulation \\
Technique \\
(RUSITEC)
\end{tabular} & $\begin{array}{l}50.25 \mathrm{~g} / \mathrm{L} \text { Citric asid, } \\
76.25 \mathrm{~g} / \mathrm{L} \text { Lactic acid }\end{array}$ & $\begin{array}{l}\text { Harder et } \\
\text { al., } 2015\end{array}$ \\
\hline $\begin{array}{l}\text { Dairy } \\
\text { Cattle }\end{array}$ & $\begin{array}{l}\text { Fumaric acid } \\
\text { Malic acid }\end{array}$ & $\begin{array}{l}\text { leaves of Robinia } \\
\text { pseudoacacia (Black } \\
\text { locust, acacia), } \\
\text { Prunus laurocerasus } \\
\text { (cherry laurel), } \\
\text { Quercus cerris (oak), } \\
\text { Camellia sinensis (tea } \\
\text { factory wastes, TFW }\end{array}$ & $\begin{array}{l}\text { ANKOM Daisy } \\
\text { II Incubator }\end{array}$ & $\begin{array}{l}0.1 \%, 0.2 \% \text { or } 0.3 \% \\
\text { Fumaric acid or } \\
\text { Malic acid }\end{array}$ & \begin{tabular}{|l|} 
Genç et al., \\
2020
\end{tabular} \\
\hline
\end{tabular}

\section{Phytobiotics}

Aromatic plants produce various essences to multiply, survive, and to protect themselves. These extracts are obtained from plants by steam distillation or extraction method. Phytobiotics that have aromatic activity are called plant extracts obtained from aromatic and spicy plants. The obtained herbal extracts are called essential oils or vegetable-essential oils. It is used to eliminate metabolic disorders, increase appetite, stimulate digestion, and benefit from its antimicrobial, antifungal, and antioxidant properties (Yeşilbağ, 2007).

Akanmu \& Hassen (2017) investigated the effects of plant extracts obtained from several medicinal herbs (Leaf fraction of Piper betle, Aloe vera, Carica papaya, Azadirachta indica, Moringa oleifera, Tithonia diversifolia, Jatropha curcas, and Moringa oleifera pods) with pure methanol on the in vitro rumen fermentation of Eragrostis curvula herb. They found that in vitro digestibility values of organic matter were superior to all extracts associated with the control group. Medjekal et al. (2017) reported that the Zingiber officinale plant increased methane and total gas but increased in vitro dry matter digestibility. Also, Nigella sativa and Rosmarinus officinalis plants have been shown to reduce in vitro dry matter digestibility while reducing methane gas production.

Zhou et al. (2020) reported that the use of oregano essential oil (13, 52, 91, and $130 \mathrm{mg} / \mathrm{L}$ ) quadratically increased the DM, NDF, and ADF digestibility. Compared with the control group, the DM and NDF digestibilities were the highest in group supplemented with $52 \mathrm{mg} / \mathrm{L}$ oregano essential oil, while the ADF digestibility was the highest in group supplemented with $91 \mathrm{mg} / \mathrm{L}$ oregano essential oil. Therefore, it revealed that $91 \mathrm{mg} / \mathrm{L}$ oregano essential oil would be the most suitable inclusion rate for future in vivo studies. Tawab et al. (2021) concluded that a mixture of thyme and celery could increase ruminal fermentation in ruminant diets, reducing gas production without any adverse effect on nutrient digestibility. However, Khorsandi et al. (2019) found that using pomegranate (Punica granatum L.) byproducts silage (PBS) at $180 \mathrm{~g} / \mathrm{kg}$ DM had higher ruminal NDF digestibility against PBS used at 60 $\mathrm{g} / \mathrm{kg}$ and $120 \mathrm{~g} / \mathrm{kg}$ DM. However, they found that using PBS at $180 \mathrm{~g} / \mathrm{kg} \mathrm{DM}$ had higher ruminal NDF digestibility against PBS used at $60 \mathrm{~g} / \mathrm{kg}$ and $120 \mathrm{~g} / \mathrm{kg}$ DM. 
Table 5: Some studies examining the effect phytogenic feed additives on in vitro digestibility recently

\begin{tabular}{|c|c|c|c|c|c|}
\hline $\begin{array}{l}\text { Animal } \\
\text { Species }\end{array}$ & Phytobiotics & $\begin{array}{l}\text { Feed used } \\
\text { (Substrate) }\end{array}$ & $\begin{array}{c}\text { In vitro } \\
\text { digestibility } \\
\text { method }\end{array}$ & Dose & References \\
\hline Sheep & $\begin{array}{l}\text { Eaf fraction of Piper } \\
\text { betle, Aloe vera, } \\
\text { Carica papaya, } \\
\text { Azadirachta indica, } \\
\text { Moringa oleifera, } \\
\text { Tithonia diversifolia, } \\
\text { Jatropha curcas, } \\
\text { Moringa oleifera } \\
\text { pods }\end{array}$ & $\begin{array}{l}\text { Eragrostis curvula } \\
\text { hay }\end{array}$ & $\begin{array}{l}\text { Gas } \\
\text { production } \\
\text { technique }\end{array}$ & $\begin{array}{l}25,50,75 \text { ve } 100 \mathrm{mg} / \mathrm{l} \\
\text { distilled water }\end{array}$ & \begin{tabular}{|l|} 
Akanmu \& \\
Hassen, \\
2017
\end{tabular} \\
\hline Sheep & $\begin{array}{l}\text { Nigella sativa, } \\
\text { Rosmarinus } \\
\text { officinalis Zingiber } \\
\text { officinale }\end{array}$ & $\begin{array}{l}\text { a mixture of } \\
\text { alfalfa hay }(500 \\
\mathrm{g} / \mathrm{kg}), \text { grass hay } \\
(400 \mathrm{~g} / \mathrm{kg}) \text { and } \\
\text { barley grain }(100 \\
\mathrm{g} / \mathrm{kg})\end{array}$ & \begin{tabular}{|l} 
Gas \\
production \\
technique
\end{tabular} & $\begin{array}{l}50 \mathrm{mg} \text { DM of each } \\
\text { plant/ } 500 \mathrm{mg} \text { DM of } \\
\text { the substrate }\end{array}$ & $\begin{array}{l}\text { Medjekal } \\
\text { et al., } 2017\end{array}$ \\
\hline Sheep & oregano essential oil & $\begin{array}{l}\text { same diet fed to } \\
\text { donor sheep }\end{array}$ & $\begin{array}{l}\text { Gas } \\
\text { production } \\
\text { technique }\end{array}$ & $13,52,91,130 \mathrm{mg} / 1$ & \begin{tabular}{|l|} 
Zhou et al., \\
2020
\end{tabular} \\
\hline Cow & $\begin{array}{l}\text { thyme plus celery } \\
\text { mix }\end{array}$ & $\begin{array}{l}60 \% \text { concentrate } \\
\text { feed mixture, } 40 \% \\
\text { clover }\end{array}$ & $\begin{array}{l}\text { Gas } \\
\text { production } \\
\text { technique }\end{array}$ & $\begin{array}{l}2.5 \text { thyme }+2.5 \text { celery } \\
\mathrm{g} / \mathrm{kg} \mathrm{DM}, 5 \text { thyme }+5 \\
\text { celery g/ kg DM, } \\
10 \text { thyme }+10 \\
\text { celery g/kg DM, }\end{array}$ & $\begin{array}{l}\text { Tawab et } \\
\text { al., } 2021\end{array}$ \\
\hline Cow & $\begin{array}{l}\text { Pomegranate } \\
\text { (Punica granatum } \\
\text { L.) by-products } \\
\text { silage }\end{array}$ & $\begin{array}{l}\text { Conventional } \\
\text { dairy cows TMR }\end{array}$ & $\begin{array}{l}\text { Gas } \\
\text { production } \\
\text { technique }\end{array}$ & $\begin{array}{l}0,60,120 \text { and } 180 \mathrm{~g} \\
\text { PBS/kg DM }\end{array}$ & $\begin{array}{l}\text { Khorsandi } \\
\text { et al., } 2019\end{array}$ \\
\hline
\end{tabular}

\section{Conclusion}

In recent years, digestibility measurement, which is of great importance for ruminant feeding due to its advantages being easy to apply and get results in a shorter time, is carried out by in vitro methods. The available literature is an evidence of many studies conducted so far in this domain except for organic acids. Many of these studies consist of alternative feed additives such as probiotics, prebiotics, enzymes, organic acids, and phytobiotics. Available in vitro studies suggest that these feed additives have positive effects on nutrient digestibility in a dose-dependent fashion. Further studies to comprehend the possible effect of organic acids on in vitro ruminal digestibility are suggested.

\section{References}

Abd El Tawab, A. M., Khattab, M. S. A., Hadhoud, F. I., \& Shaaban, M. M. (2021), Effect of mixture of herbal plants on ruminal fermentation, degradability and gas production, Acta Scientiarum. Animal Sciences, 43, e48549-e48549.

Adesogan, A. T. (2005), Effect of bag type on the apparent digestibility of feeds in ANKOM DaisyII incubators, Animal feed science and technology, 119(3-4), 333-344.

Akanmu AM, Hassen A (2018), The use of certain medicinal plant extracts reduced in vitro methane production while improving in vitro organic matter digestibility, Anim. Prod Sci. 58(5), 900908.

Arowolo, M. A., \& He, J. (2018), Use of probiotics and botanical extracts to improve ruminant production in the tropics: A review, Animal Nutrition, 4(3), 241-249. 
Badhan, A., Ribeiro Jr, G. O., Jones, D. R., Wang, Y., Abbott, D. W., Di Falco, M., ... \& McAllister, T. A. (2018). Identification of Novel Enzymes to Enhance the Ruminal Digestion of Barley Straw, Bioresource technology, 260, 76-84.

Cherry, P., Yadav, S., Strain, C. R., Allsopp, P. J., McSorley, E. M., Ross, R. P., \& Stanton, C. (2019), Prebiotics from seaweeds: An ocean of opportunity? Marine drugs, 17(6), 327.

Czerkawsk1, J. W., Breckenridgee, G. (1977), Design and development of a long term rumen simulation technique (Rusitec), British journal of nutrition, 38, 371-384.

Elghandour, M. M., Chagoyán, J. C. V., Salem, A. Z., Kholif, A. E., Castañeda, J. S. M., Camacho, L. M., \& Cerrillo-Soto, M. A. (2014), Effects of Saccharomyces cerevisiae at direct addition or pre-incubation on in vitro gas production kinetics and degradability of four fibrous feeds, Italian Journal of Animal Science, 13(2), 3075.

Elghandour, M. M., Salem, A. Z., Castañeda, J. S. M., Camacho, L. M., Kholif, A. E., \& Chagoyán, J. C. V. (2015), Direct-fed microbes: A tool for improving the utilization of low-quality roughages in ruminants, Journal of Integrative Agriculture, 14(3), 526-533.

Gado, H. M., Khusro, A., \& Salem, A. Z. M. (2017), Role of probiotics in animal nutrition, Animal Review, 4(1), 8-20.

Garipoğlu, A.V. (2015), An alternative Method for Determining the Feed Digestibility: FNIRS (Faecal Near Infrared Reflectance Spectroscopy).

GENÇ, B., Salman, M., BÖLÜKBAŞ, B., Kaya, I., \& Acici, M. (2020), The effects of fumaric and malic acids on the in vitro true digestibility of some alternative feedstuffs for ruminants, Ankara Üniversitesi Veteriner Fakültesi Dergisi, 67(2), 185-192.

Goering, H. K., Van Soest, P. J. (1970), Forage fiber analyses: apparatus, reagents, procedures, and some applications, Agricultural Research Service 379, US Department of Agriculture.

Goiri, I., Oregui, L. M., \& Garcia-Rodriguez, A. (2010), Use of chitosans to modulate ruminal fermentation of a 50: 50 forage-to-concentrate diet in sheep, Journal of animal science, 88(2), 749-755.

Harder, H., Khol-Parisini, A., Metzler-Zebeli, B. U., Klevenhusen, F., \& Zebeli, Q. (2015), Treatment of grain with organic acids at 2 different dietary phosphorus levels modulates ruminal microbial community structure and fermentation patterns in vitro, Journal of Dairy Science, 98(11), 8107-8120.

Hassan, A., Gado, H., Anele, U. Y., Berasain, M. A., \& Salem, A. Z. (2020). Influence of dietary probiotic inclusion on growth performance, nutrient utilization, ruminal fermentation activities and methane production in growing lambs. Animal biotechnology, 31(4), 365-372.

Karakus, K., Karakus, S., Celikyurek, H. (2019), Ülke Toprakları ve Tarım Arazilerinin Bitkisel ve Hayvansal Üretim Faaliyeti Dışında Kullanımı, Hayvan Bilimi ve Ürünleri Dergisi, 2(1), 84-90.

Kellems, R. O., Church D. C. (2010), Livestock Feeds and Feeding, $6^{\text {th }}$ ed. Iowa: Pearson Publishing p. 35-48.

Khorsandi, S., Riasi, A., Khorvash, M., \& Hashemzadeh, F. (2019), Nutrient's digestibility, metabolic parameters and milk production in postpartum Holstein cows fed pomegranate (Punica granatum L.) by-products silage under heat stress condition, Animal Feed Science and Technology, 255, 114-213.

Kılıç, Ü, Sarıçiçek, B. Z. (2006),’In Vitro Gaz Üretim Tekniğinde Sonuçları Etkileyen Faktörler, Hayvansal Üretim, 47(2), 54-61. 
Kocaoğlu Güçlü, B. \& Kara, K. (2010), Use of Alternative Feed Additives in Ruminant Nutrition: 2. Organic Acid, Fatty Acid, Adsorbent, Erciyes Üniversitesi Veteriner Fakültesi Dergisi 7(1), 4352.

Kondratovich, L. B., Sarturi, J. O., Hoffmann, C. A., Ballou, M. A., Trojan, S. J., \& Campanili, P. R. (2019), Effects of dietary exogenous fibrolytic enzymes on ruminal fermentation characteristics of beef steers fed high-and low-quality growing diets, Journal of animal science, 97(7), 30893102 .

Li, L., Qu, M., Liu, C., Pan, K., Xu, L., OuYang, K., ... \& Zhao, X. (2019), Expression of a recombinant Lentinula edodes cellobiohydrolase by Pichia pastoris and its effects on in vitro ruminal fermentation of agricultural straws, International journal of biological macromolecules, 134, 146-155.

McAllister, T.A., Hristov, A.N., Beauchemin, K.A., Rode, L.M., Cheng, K.J., (2001), Enzymes in Ruminant Diets, Bedford MR, Partridge GG. Enzymes in Farm Animal Nutrition. UK: Bowman CABI Publishing. pp. 273-298.

Menke, K. H., Raab, L., Salewski, A., Steingass, H., Fritz, D., \& Schneider, W. (1979), The estimation of the digestibility and metabolizable energy content of ruminant feedingstuffs from the gas production when they are incubated with rumen liquor in vitro, The Journal of Agricultural Science, 93(1), 217-222.

Ogunade, I. M., \& McCoun, M. (2021), Effects of adding live Saccharomyces cerevisiae and Aspergillus-based enzyme extracts on ruminal fermentation, plasma polyamine concentrations, and fiber digestibility in beef steers fed a high-forage diet, Applied Animal Science, 37(1), 2126.

Ribeiro, G. O., Badhan, A., Huang, J., Beauchemin, KA, Yang, W, Wang, Y et al. (2018), New recombinant fibrolytic enzymes for improved in vitro ruminal fiber degradability of barley straw, Journal of animal science, 96(9), 3928-3942.

Salman M, Cetinkaya N, Selcuk Z, Genc B, Acici M (2017), Effects of various inulin levels on in vitro digestibility of corn silage, perennial ryegrass (Lolium perenne L.) and common vetch (Vicia sativa L.) /oat (Avena sativa L.) hay, S Afr J Anim Sci, 47 (5), 723-729.

Santoso, B., Widayati, T. W., \& Hariadi, B. T. (2020), Improvement of fermentation and the in vitro digestibility characteristics of agricultural waste-based complete feed silage with cellulase enzyme treatment, Advances in Animal and Veterinary Sciences, 8(8), 873-881.

Seankamsorn, A., Cherdthong, A., \& Wanapat, M. (2020), Combining crude glycerin with chitosan can manipulate in vitro ruminal efficiency and inhibit methane synthesis, Animals, 10(1), 37.

Seifdavati, J., Seifzadeh, S., Ramezani, M., Mashak, R. B., Seyedsharifi, R., Elghandour, M. M., ... \& Salem, A. Z. (2021), Wastes Valorization of Wheat Straw and Wheat Bran Treated with Urea, Probiotic or Organic Acids to Enhance Ruminal Gas Production and Digestibility of Pumpkin By-product, Waste and Biomass Valorization, 1-11.

Singh, A. K., Kerketta, S., Yogi, R. K., Kumar, A., \& Ojha, L. (2017), Prebiotics: the new feed supplement for dairy calf, Int J Livest Res, 7, 1-17.

Singh, R., \& Saini, A. K. (2020), Effect of Mannan Oligosaccharides (MOS) to Ameliorate Adverse Effects of Aflatoxin on In Vitro Rumen Fermentation of a Buffalo Diet, Veterinary Research, 8(02), 78-84.

Sujani, S., \& Seresinhe, R. T. (2015), Exogenous enzymes in ruminant nutrition: A review, Asian Journal of Animal Sciences, 9(3), 85-99. 
Tassone, S., Fortina, R., \& Peiretti, P. G. (2020), In Vitro Techniques Using the DaisyII Incubator for the Assessment of Digestibility: A Review, Animals, 10(5), 775.

Tilley, J. M. Terry (1963). RA A two stage for the in vitro digestion of forage crops, Journal of The British Grassland Society, 18, 104-111.

van der Poel, A. F. B., Abdollahi, M. R., Cheng, H., Colovic, R., den Hartog, L. A., Miladinovic, D., ... \& Hendriks, W. H. (2020), Future directions of animal feed technology research to meet the challenges of a changing world, Animal Feed Science and Technology, 270, 114692

Wenk, C. (2000), Recent advances in animal feed additives such as metabolic modifiers, antimicrobial agents, probiotics, enzymes and highly available minerals-review, AsianAustralasian Journal of Animal Sciences, 13(1), 86-95.

Yang, H. J., Tamminga, S., Williams, B. A., Dijkstra, J., \& Boer, H. (2005), In vitro gas and volatile fatty acids production profiles of barley and maize and their soluble and washout fractions after feed processing, Animal Feed Science and Technology, 120(1-2), 125-140.

Yeşilbağ D. (2007), Fitobiyotikler, Uludag Univ J Fac Vet Med, 26, 33-39.

Zhang, Q., Yang, H. ve Yu, Z. (2017), Sakaroz, formik asit ve laktik asit bakteri aşılayıcısının sarkık yabani çavdar (Elymus nutans Griseb.) Silajının kalitesi, in vitro işkembe sindirilebilirliği ve fermente edilebilirliği üzerindeki etkileri, Journal of Animal and Feed Sciences, 26 (1), 26-32. 